\title{
Peran Perawat Dalam Penerapan 'PHC' Pada Pelayanan Kesehatan Ibu dan Anak - Keluarga Berencana
}

\author{
JUNAITI SAHAR
}

\begin{abstract}
Abstrak
Penelitian ini menggunakan desain penelitian eksploratif yang bertujuan menguraikan kegiatan yang dilakukan perawat dan mengindentifikasi faktor yang mempengaruhi kegiatan perawatan dalam pelayanan KIA dan KB di Puskesmas dan di masyarakat. Penelitian dilakukan terhadap empat perawat yang masing-masing bekerja di Puskesmas Induk dan Puskesmas Pembantu di Bogor dan Puskesmas Induk dan Puskesmas Pembantu di Depok. Tiap perawat diamati oleh dua orang peneliti selama jam kerja untuk mengetahui jumlah waktu yang digunakan untuk kegiatan KIA dan KB. Hasil penelitian menunjukkan bahwa prosentase waktu rata-rata yang digunakan perawat untuk pelayanan KIA dan KB adalah $29,6 \%$ dari total waktu pelayanan Puskesmas. Waktu yang lain digunakan oleh perawat untuk melaksanakan kegiatan pemeriksaan, penyuntikan, pengisian kartu pemanggil pasien dan menyiapkan obat. Perawat yang bekerja pada Puskesmas di Bogor menunjukkan bobot kegiatan paling tinggi dalam pelayanan KIA dan KB, sedangkan tiga perawat lainnya, hanya melakukan kegiatan pada Balai Pengobatan, depot obat dan kegiatan non keperawatan lain. Kegiatan perawat tertinggi di Posyandu adalah pemberian imunisasi dan pemantauan pertumbuhan yaitu 89,3\% dari kegiatan lain. Puskesmas yang memberikan kewenangan yang lebih besar kepada perawat dan perawat dengan kemampuan lebih untuk melakukan pelayanan KB, ternyata menunjukkan cakupan KB yang cukup tinggi, yaitu $82,4 \%$. Beberapa faktor yang menyebabkan perawat kurang berperan dalam pelayanan KIA dan KB antara lain karena perawat tidak diberikan kewenangan untuk memberikan pelayanan KIA dan KB, serta uraian tugas yang kurang jelas dan tidak sesuai dengan latar belakang pendidikan perawat.
\end{abstract}

Kata kunci : Metodologi deskriptif-eksploratif, korelasi positif, praktek keperawatan mandiri, keperawatan profesional.

\begin{abstract}
This resort utilized exploratif descriptive design with the purpose of describing the nurse's activities and identification of factor affective nursing activities in maternal child healt care and family planning services in health center and community. For nurses working at twograin health center and to subdistrict health center located in Bogor and Depok were included in this study. Each nurse was observed by two observers throughout the working in hours to collect data on time spent bu nurses for maternal child health care and family planning services. The result of study revealed that the average of presentage time spent by nurses to provide maternal child health care and family planning sevices was $26,6 \%$ of total time spent in health center. The rest of time was spent by nurses for non-nursing activities such as examination parenteral medication, filling out frames, calling for patients and preparing the madication. The nurse who worked at health center in Bogor. Showed the most time spent for maternal child health care and family planning services, while another three nurses only worked at medical room, and drug counter and did non-nursing activities. Imunization and mentoring of child growth were reported as the most activities done (89,3\%) at integrated health post (Posyandu) compared to another nurses's activities. The health center with more autonomy giren to the nurses and asses with more competencies to provide family planning services that infact had an high coverage of family planning which was $82,4 \%$. Several factors affecting the low contributing of nurses on mater hal child health care of family planning have been identified in this study were that those nurses were not authorized to offer maternal child health care of family planning, and the unclear job descriptions, as well ad inadequate educational background of nurses.
\end{abstract}

Key word : Explorative descriptive design, positive correlation, independent nursing sevice, professional nursing service. 